\title{
Rural Children Now Less Likely to Live in Married-Couple Families
}

\author{
WILLIAM P. O'HARE AND ALLISON CHURILLA
}

$I^{\prime}$ n 1990, rural children were more likely to be living in married-couple families than children living in urban areas. Today, however, that has changed. The most recent data from the Census Bureau shows that rural children are now slightly less likely to be living in marriedcouple families.

In 1990, 76 percent of rural children were living in married-couple families compared with 72 percent of those in central cities and suburbs (metropolitan areas). In the early 1990s, marriage declined in both areas, but urban rates bottomed out at 68 percent in 1995. For rural families, the share of children living in married-couple families fluctuated in the late 1990s, but then plunged from 73 percent in 2000 to 68 percent in 2008 . The most recent data available for 2008 indicate that the share of rural children living in married-couple families is 1 percentage point below that of children in metropolitan areas (68 percent versus 69 percent).

Family structure is closely linked to a variety of child outcomes and numerous studies have shown that, in general, children growing up in a stable, married-couple family have more advantages and opportunities than those growing up in a single-parent family. ${ }^{1}$ The poverty rate for children in married-couple families is 9 percent compared to 21 percent for those in male-headed and 43 percent for those in female-headed families. ${ }^{2}$ Consequently, the decline in the share of rural children living in married-couple families since 2000 may help explain the 3 percentage point rise in child poverty in rural America between 2000 and $2006 .^{3}$

Divergent paths of family structure in rural and urban America are masked by overall nationwide change since 1990. Table 1 shows that the share of children in marriedcouple families declined from 73 percent in 1990 to 69 percent in 1996, and has shown little change since.
Overall metropolitan rates also mask important changes within central cities and suburbs. The share of centralcity children living in married-couple families increased from 56 percent in 1995 to 61 percent in 2008. During the same period, the percentage of suburban children living in married-couple families fell from 76 to 74 percent.

TABle 1. Percentage OF CHILDREN LIVING IN MARRIEDCOUPLE FAMILIES BY METRO STATUS, 1990-2008

\begin{tabular}{lccccc}
\hline & TOTAL & RURAL & \multicolumn{3}{c}{ URBAN (INSIDE METROS) } \\
\cline { 2 - 6 } & & $\begin{array}{c}\text { (Outside } \\
\text { Metros) }\end{array}$ & $\begin{array}{c}\text { Total } \\
\text { Urban }\end{array}$ & $\begin{array}{c}\text { Central } \\
\text { City }\end{array}$ & Suburbs \\
\hline 1990 & $73 \%$ & $76 \%$ & $72 \%$ & $61 \%$ & $79 \%$ \\
\hline 1991 & $73 \%$ & $76 \%$ & $71 \%$ & $60 \%$ & $79 \%$ \\
\hline 1992 & $72 \%$ & $77 \%$ & $70 \%$ & $58 \%$ & $78 \%$ \\
\hline 1993 & $71 \%$ & $75 \%$ & $70 \%$ & $57 \%$ & $78 \%$ \\
\hline 1994 & $71 \%$ & $74 \%$ & $69 \%$ & $57 \%$ & $77 \%$ \\
\hline 1995 & $70 \%$ & $73 \%$ & $68 \%$ & $56 \%$ & $76 \%$ \\
\hline 1996 & $69 \%$ & $71 \%$ & $69 \%$ & $55 \%$ & $77 \%$ \\
\hline 1997 & $69 \%$ & $70 \%$ & $69 \%$ & $56 \%$ & $77 \%$ \\
\hline 1998 & $69 \%$ & $69 \%$ & $69 \%$ & $58 \%$ & $76 \%$ \\
\hline 1999 & $69 \%$ & $71 \%$ & $69 \%$ & $56 \%$ & $76 \%$ \\
\hline 2000 & $70 \%$ & $73 \%$ & $70 \%$ & $59 \%$ & $76 \%$ \\
\hline 2001 & $71 \%$ & $71 \%$ & $70 \%$ & $60 \%$ & $76 \%$ \\
\hline 2002 & $70 \%$ & $69 \%$ & $70 \%$ & $59 \%$ & $76 \%$ \\
\hline 2003 & $70 \%$ & $70 \%$ & $70 \%$ & $58 \%$ & $76 \%$ \\
\hline 2004 & $69 \%$ & $70 \%$ & $69 \%$ & $57 \%$ & $75 \%$ \\
\hline 2005 & $69 \%$ & $69 \%$ & $69 \%$ & $58 \%$ & $75 \%$ \\
\hline 2006 & $69 \%$ & $68 \%$ & $69 \%$ & $61 \%$ & $74 \%$ \\
\hline 2007 & $69 \%$ & $66 \%$ & $70 \%$ & $63 \%$ & $74 \%$ \\
\hline 2008 & $69 \%$ & $68 \%$ & $69 \%$ & $61 \%$ & $74 \%$ \\
\hline
\end{tabular}


Figure 1. Percentage of Children living in MARried-COUPle FAMilies by Metro Status, 1990-2008

$90 \%$

$85 \%$

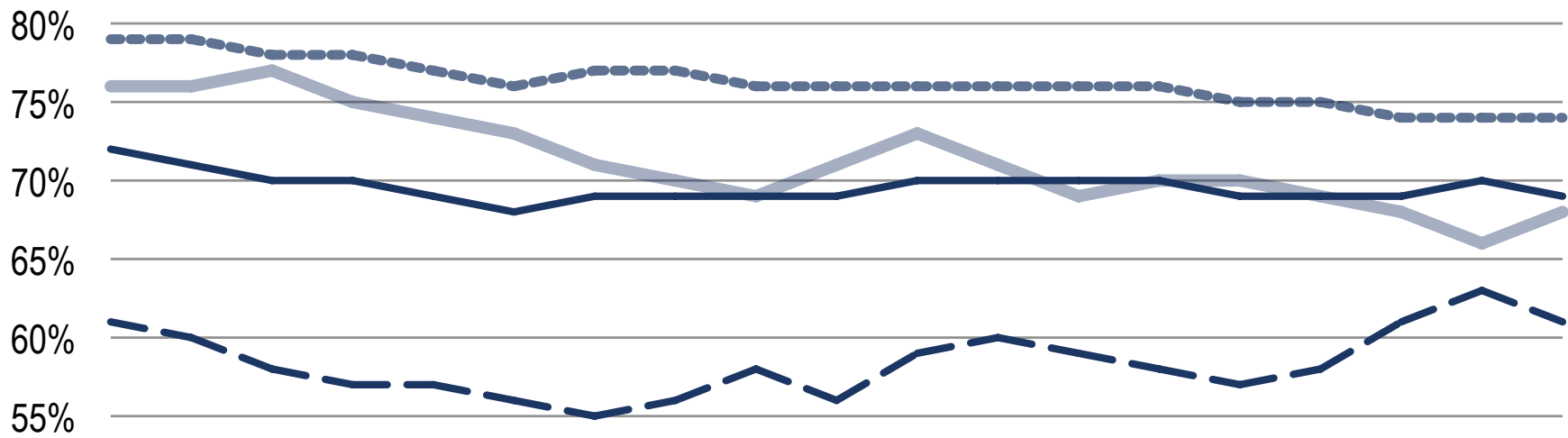

$50 \%$

$45 \%$

$40 \%$

1990

1993

1996

1999

2002

2005

\section{Nonmetropolitan - All Metropolitan - Central City $\cdots$ Suburbs}

Source: March Current Population Survey, Various Years

Nоте: Metropolitan areas are comprised of central cities and suburbs; data for these two geographies are

disaggregated to illustrate distinct patterns.

\section{Endnotes}

1 Sandefur, Gary and Sara S. McLanahan. 1994. Growing up with a Single Parent: What Hurts, What Helps. Cambridge, MA: Harvard University Press.

2 U.S. Census Bureau. 2008. “Table POV02: People in Families by Family Structure, Age, and Sex Interated by Income-to-Poverty Ratio and Race: 2007 , Below $100 \%$ of Poverty-All Races.” Retrieved October 7, 2008 (http:// pubdb3.census.gov/macro/032008/pov/new02_100_01.htm).

3 O’Hare, William P. and Sarah Savage. 2007. "Child Poverty High in Rural America.” Fact Sheet No. 6, Carsey Institute at the University of New Hampshire, Durham, NH.

\section{Authors}

William P. O'Hare is a senior fellow at the Carsey Institute.

Allison Churilla is a policy fellow at the Carsey Institute and a Ph.D. candidate in the Department of Sociology at the University of New Hampshire (allison.churilla@unh.edu).

\section{CARSEY I N S T I T U T E}

Building KNOWLEdGE FOR FAMILIES AND COMMUNities
Huddleston Hall, 73 Main Street, Durham, NH 03824

(6o3) 862-2821 • www.carseyinstitute.unh.edu

This brief is part of a series of Carsey Institute Reports on

Rural America. 